\title{
Suriye İç Savaşında Yabancı Savaşçılar
}

\section{Mustafa Tayfun ÜSTÜN ${ }^{1}$}

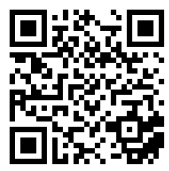

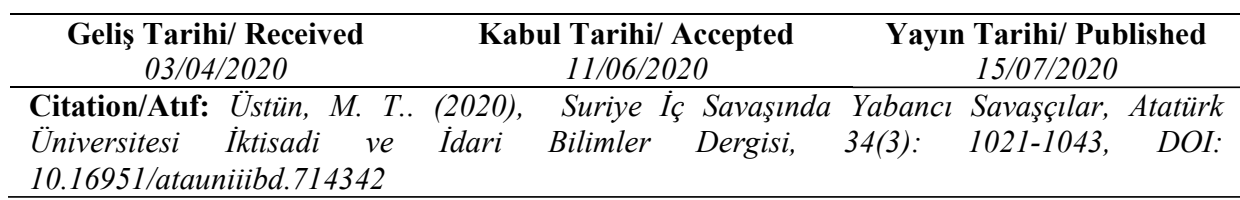

Öz: Bu çalışma Suriye iç savaşında bir aktör haline dönüşmüş olan yabancı savaşçılar hakkındadır. Üç kısımdan oluşan çalışmada ilk olarak yabancı savaş̧̧ı teriminin (indirgemecilik tuzağına düşmemek adına) literatürdeki kullanımları dikkate alınarak kavramsal analizi yapılacaktır. Hali hazırda farklı yazarlar yabancı savaşçı teriminin değişik taraflarını vurgulayarak kavramsallaştırma sürecine katkıda bulunmalarına karşın, üzerinde uzlaşılan ortak bir tanıma rastlamak mümkün değildir. Yabancı savaşçı kavramının belirleyici özellikleri ve uzlaşılan tanımın önündeki engeller bu kısımda üzerinde durulacak konular olacaktır. Çalışmanın ikinci kısımda ise yabancı savaşçıların bölgedeki faaliyetleri kapsamında istikrarı nasıl etkilediği tartışılarak, sonrasında uyruğu oldukları ülkelerde ne gibi problemler yarattığ 1 ve bunlara karşı ülkelerin aldığı tedbirler üzerinde durulacaktır. Mevcut literatürden anlaşıldığ 1 üzere yabancı savaşçı olgusu sadece savaştıkları bölgeyle ilgili sorun oluşturmamaktadır. Aksine uyruğu olduğu ülkelerdeki sosyal yapıyı ve bu ülkelerin diplomatik ilişkilerini de etkileyebilmektedir. Çalışmada, yabancı savaş̧̧ıların silahaltına alınmasının, bölgedeki faaliyetlerinin, gözetimlerinin, geri dönüşlerinin ve rehabilitasyonlarının güvenlik, istikrar ve uluslararası hukuk açısından yeni tartışmalar doğurduğu ve bu sorunlarla küresel düzeydeki iş birlikleriyle mücadele edilebileceği ileri sürülmektedir.

Anahtar Kelimeler: Yabancı Savaşçı, Terörizm, Suriye, Uluslararası Hukuk, Savaş

\section{Foreign Fighters in The Syrian Civil War}

Abstract: This paper is about foreign fighters becoming actors in the Syrian civil war. It consists of three sections. Firstly, the concept of foreign fighters will be analyzed by referring to various usage of the term in the literature in order to avoid reductionism. It is hard to come across a consensus on the term of foreign fighters even though some scholars contribute to the process of conceptualization by emphasizing different aspects. The deterministic features of the term and obstacles towards agreed definition will be discussed in this section. Secondly, it will be examined how foreign fighters affect security and stability in the region. Finally, possible causes and measurements that can be observed in the countries where foreign fighters have nationality will be elaborated. As understood from the literature, the phenomenon of foreign fighter causes problems not only in the region where they fight. Indeed, they can shape social structures of origin countries and their diplomatic relations. In this paper, it is argued that recruiting, activities, surveillance, return and rehabilitation of foreign fighters bring forth new debates in terms of security, stability and international law. Also, it is believed that these issues can be overcome by collaborations at the global level.

Key Words: Foreign Fighter, Terrorism, Syria, International Law, War

${ }^{1}$ Dr. Ögrr. Üyesi, Atatürk Üniversitesi, İktisadi ve İdari Bilimler Fakültesi, Uluslararası İlişkiler Bölümü, https://orcid.org/0000-0002-9562-8911 


\section{Background}

\section{EXTENDED SUMMARY}

As a result of the Arab Spring in 2010, socio-cultural, economic and political dynamics began to change. Conflicts that are observed have become international and multidimensional consisting of various actors. Especially, increasing the numbers of the non-state actors leads most known war strategies to be changed. Trans-national extremist fighters and troops have begun to replace regular armies and front battles.

\section{Research Problem}

This paper is about the phenomenon of foreign fighters. In the case of the Syrian Civil War, it seeks to understand how foreign fighters affect security and stability in the region by examining their activities in the field. Additionally, it aims to put forward possible issues which can be observed in origin as well as host countries where foreign fighters return or settle down. It is believed that foreign fighters cause serious problems in terms of international law and move conflict and violence to conflict-free zones.

\section{Research Question}

- This paper primarily answers the following questions;

- How do foreign fighters affect security and stability?

- What are the major activities of foreign fighters?

- What can prominent issues be observed in international law?

- What are the possible measurements and responses of the state towards foreign fighters?

\section{Literature Review}

It is likely to argue that the concept of foreign fighters is highly popular in IR. Some tend to examine foreign fighters from a historical point of view while others focus on the concept at individual level and seek to understand why people tend to fight in foreign lands. As is understood from the current literature, the concept of foreign fighters generally is considered to call people those who leave their home town in the West. It is used for militias joining in Islamist radical groups. This paper differs from previous works in three points. First of all, it is not designed at the individual or group level seeking to understand motivations or the participation process behind foreign fighters. Rather, it focuses on relations between foreign fighters and insecurity and instability in the region. Their activities and consequences not only in the region but also origin countries help this paper to differ from. Secondly, this paper seeks to understand measurements which are applied by origin countries to prevent and deal with the phenomenon of foreign fighters. Therefore, it is likely to come across more tangible policies throughout the study. Thirdly, importantly, this paper distinguishes from other works by approaching the concept of foreign fighters and foreign terrorist fighters. It not only uses the term for Islamist radical groups but also it argues that people those who join YPG-PKK by ethnic and leftist motivations should be 
considered as foreign terrorist fighters. Since both groups jeopardise the security and stability in the region. In this paper, observation notes and reports which have been issued by non-governmental organisations, reports of the councils of the UN and policy papers are benefited as primary sources.

\section{Methodology}

By focusing on these sources, this paper compares activities of these terror groups in the region and analyzes how they impact the stability. Also, it puts forward to measurements of the origin countries and possible problems comparatively. It is likely to argue that this paper is designed as an empirical point of view.

\section{Result}

In this paper, it is argued that recruiting, activities, surveillance, return and rehabilitation of foreign fighters bring forth new debates in terms of security, stability and international law. There is no doubt that activities of the foreign fighters in the region are clear violations of human rights. This paper shows that there is a direct correlation between their activities and mass migration. Civilians who were suppressed by these groups have tended to flee their home towns. Therefore, the circle of insecurity has been enlarged by involving neighbouring countries. Another result highlighted by the paper is that states tend to adopt different approaches; namely, hard and soft policies to deal with returners. Some countries punish their citizens who became foreign fighters while others are developing rehabilitation programs. This paper argues that both approaches are imperfect and come with some disadvantages. Foreign fighters cause the serious cost for the origin and other countries. Moreover, sharing responsibilities about trials increases the violation of human rights because the judiciary and political system in the countries where foreign fighters are arrested are very weak if it is compared to the EU. Therefore, this enlarges the instability. Also, it is believed that these issues can be overcome by collaborations at the global level.

\section{Giriş}

2010'da başlayan Arap Baharı'nın sonucu olarak Ortadoğu bölgesinin sosyo-kültürel, ekonomik ve siyasal dengelerinde değişimler meydana gelmeye ve çeşitli aktörlerin müdahil olduğu çok boyutlu ve uluslararası çatışmalar görülmeye başlanmıştır. Özellikle devlet-dış1 aktörlerin sayılarındaki artış bilindik savaş stratejilerinin değişmesine yol açmıştır. Düzenli ordular ve cephe savaşlarının yerini dünyanın farklı bölgelerinden gelen ulus-ötesi aşırıcı birlikler doldurmuştur.

Suriye, bölgenin genelinde görülen dönüşüm ve çatışma ikliminden derinden etkilenmiştir. 2011 yılında Suriye'nin Der'a kentinde rejime karş1 başlayan protestolar kısa bir süre içerisinde ülkenin diğer şehirlerine de yayılarak istikrarın ortadan kalkmasına ve birçok yerel ve uluslararası aktörün dâhil olduğu kanlı bir iç savaşın ortaya çıkmasına neden olmuştur. Rejim güçleri ve muhalifler arasında yaşanan çatışmaların bir sonucu olarak binlerce insan hayatını 
kaybederken, milyonlarca insan ise (yaklaşık olarak 6 milyon) çevre ülkelere göç etmek zorunda kalmıştır (Birleşmiş Milletler İnsan Hakları Konseyi [UNHRC], 2020). Yaşanan bu göç dalgası, hem ev sahibi ülkeler açısından hem de göçmen ve mülteciler açısından uluslararası toplumda önemli tartışmaları ve gelişmeleri beraberinde getirmiştir.

Suriye'de ise siviller tarafından boşalan bu topraklar aktörlerin güç mücadelesine giriştiği sahalar haline gelmiştir (Ünver, 2018: 35). 2011-2015 yılları arasında rejim kuvvetlerinin bazı toprakları terk etmesi bölgenin devlet dış1 aktörlerin denetimine girmesine yol açmıştır. Dini ya da etnik sol motifli saiklerle bu aktörler toprakları kontrol etmeye ve aynı zamanda bölgedeki faaliyetleriyle güvensizlik ve istikrasızlık ortamının derinleşmesine yol açmıştır. Bu alanlarda devlet dışı aktörler, tersine bir göç eğiliminin ortaya çıkmasına ve hızlanmasına zemin hazırlamıştır. Bireysel veya kitlesel düzeyde gerçekleşen bu göçlerle birlikte bölgeye çok sayıda militan akın etmiştir. 110 ülkeden bölgeye yönelik sayıları 40000'e varan bir göç trendi gözlenmiştir (Barrett, 2017: 7; Orton, 2017:116). Bu göç hareketi yabancı savaşçı olgusunu tekrar uluslararası ilişkilerin gündemine sokmuştur. Yabancı savaşçılar bir yandan kavramsal düzeyde diğer yandan ise pratik düzeyde tartışlırken neden binlerce insanın yabancısı oldukları topraklarda savaşmak istedikleri, bölgeyi nasıl istikrarsızlık ve güvensizlik çemberine soktukları ve başta uyruğu olduğu ülkelerde ve üçüncü ülkelerde ne gibi problemler doğurduğu/doğurabileceği cevaplanmayı bekleyen sorular arasındadır. Bireysel ya da örgütsel düzeyde yaklaşım benimsenerek yabancı savaşçı olgusu analiz edilmeye çalışılmaktadır.

$\mathrm{Bu}$ çalışma Suriye iç savaşında bir aktör haline dönüşmüş olan yabancı savaş̧̧ılar hakkındadır. Üç kısımdan oluşan çalışmada ilk olarak yabancı savaşçı teriminin (indirgemecilik tuzağına düşmemek adına) literatürdeki kullanımları dikkate alınarak kavramsal analizi yapılacaktır. Hali hazırda farklı yazarlar yabancı savaşçı teriminin değişik taraflarını vurgulayarak kavramsallaştırma sürecine katkıda bulunmalarına karşın, üzerinde uzlaşılan ortak bir tanıma rastlamak mümkün değildir. Yabancı savaşçı kavramının belirleyici özellikleri ve uzlaşılan tanımın önündeki engeller bu kısımda üzerinde durulacak konular olacaktır. Çalışmanın ikinci kısımda ise yabancı savaşçıların bölgedeki faaliyetleri kapsamında istikrarı nasıl etkilediği tartış1larak, sonrasında uyruğu oldukları ülkelerde ne gibi problemler yarattığı ve bunlara karşı ülkelerin aldığ1 tedbirler üzerinde durulacaktır. Mevcut literatürden anlaşıldığı üzere yabancı savaş̧̧ı olgusu sadece savaştıkları bölgeyle ilgili sorun oluşturmamaktadır. Aksine uyruğu olduğu ülkelerdeki sosyal yapıyı ve bu ülkelerin diplomatik ilişsilerini de etkileyebilmektedir. Çalışmada, yabancı savaşçıların silah altına alınmasının, bölgedeki faaliyetlerinin, gözetimlerinin, geri dönüşlerinin ve rehabilitasyonlarının; güvenlik, istikrar ve uluslararası hukuk açısından yeni tartışmalar doğurduğu ve bu sorunlarla küresel düzeydeki iş birlikleriyle mücadele edilebileceği ileri sürülmektedir. 


\section{Yabancı Savaşçı Olgusu}

Yabancı savaşçı, devlet dışı silahlı aktörler kapsamında uluslararası ilişkiler disiplini içerisinde kullanılan bir kavramdır. Her ne kadar terimin kavramsallaşması çok yakın dönemlere (2000'li yılların başlarına) denk gelse de, yabancı savaşçıların tarihi oldukça eskiye dayanmaktadır. Tarihin değişik safhalarında farklı motivasyonlar ve ideolojiler insanların yabancısı oldukları coğrafyalarda savaşmalarına zemin hazırlamıştır. Akademik literatürde yabancı savaşçı olgusu genellikle ulus devletlerin ortaya çıktı̆g on dokuzuncu yüzyılın sonlarıyla ilişkilendirilmektedir (Yalçınkaya, 2017: 25). Bu bakış açısının ortaya çıkmasının ulus devletlerin sınırları ve uluslaşma süreçleriyle yakından ilgili olduğu ileri sürülmektedir. Egemen ve sınırları belli bir devlet içinde vatandaş ordularının kurulması "yabancı savaşç" kavramını öne çıkarmıştır. Çünkü dönem itibariyle kurulan devletler homojen olmaktan uzaktı ve kimlikler çok belirgin değildi. İçlerinde dilsel, dinsel ve etnik olarak azınlık gruplarını barındırmışıtır. Bu farklı gruplar ya da bireyler, devletlerin savaşlarına müdahil olmaktan çekinmemişlerdir. On dokuzuncu yüzyıldan itibaren Yunan İsyanı (1821-1832), Teksas Bağımsızlık Savaşı (1835-1836); 20. Yüzyıldaki İspanyol İç Savaş1 (1936-1939), Arap-İsrail Savaş1 (1948), Afganistan Savaşı (19791989), eski Yugoslavya'nın dağılması esnasında yaşanan olaylar (1991-1995) ve Somali'deki çatışmalar (2006-2009) yabancı savaşçıların çatışma alanlarında görüldüğü örnekler arasında düşünülebilir (Yalçınkaya, 2017:25). Yabancı savaşçılar imparatorluk ve sömürgeci güçler tarafından etkin olarak kullanılmıştır (Hatahet vd, 2019:5-6.)

Fakat yabancı savaşçılar olgusunun oldukça dinamik olduğunu belirtmek gerekir. Tarihsel süreç içerisinde anlamı ve algılanışı sürekli değişen bir olgu olmuştur. Günümüzde yabancı savaş̧̧ılar hakkında yapılan kavramsallaştırma çalışmaları kavramı farklı bir boyuta taşırken aynı zamanda üzerinde anlaşılan bir tanımın ortaya çıkmasını da zorlaştırmaktadır. Akademik literatürde konu üzerine çalışanlar, yabancı savaşçı olgusunu teorik ve kavramsal çerçeveye oturmaya çalışmaktadır. Bu akademisyenlerden biri olan Malet 1815-2015 yılları arasında yaşanan iç savaşları analiz ederek yabancı savaşçılar üzerine tipoloji geliştirmeye çalışmıştır. Yabancı savaşçı olgusu Malet'e göre etnik ve etnik olmayan biçimlerde görülebilmektedir. Yabancı savaşçılar ise bu çatışmalara kimlikleri vasıtasıyla müdahil olmaktadır (Malet, 2013: 45-46). Farklı biçimde ifade etmek gerekirse kimi savaşçılar çatışmalarla aynı kimlik düzeyinde bulunurken, kimileri farklı sosyal ve politik kimliklerle bu çatışmaların bir parçası olmaktadır. Malet çatışmaya katılım düzeyinde yabancı savaş̧̧ıların 4 farklı biçimde karşımıza çıkabileceğini ileri sürmüştür. Eğer yabancı savaşçılar milliyetçi amaçlar doğrultusunda örgütlenirse "diaspora", ideolojik hedefleri korumak ve sömürge karşıtı savaşlara katılırsa "özgürlükçü", komşu ülkelerdeki siyasi isyancılara destek vermek için katılırsa "istilacı" ve paylaşılan kimliğin kurumlarını korumak için ideolojik isyancılarla beraber savaşmaya girerse "gerçek inananlar" olarak isimlendirilebilir. Belirtmek gerekir ki Malet her ne 
kadar farklı yabancı savaşçı tipolojilerinden bahsetmiş olsa da yabancı savaşçı kavramının en belirgin özelliği hiçbir savaşçının çatışmanın yaşandığı bölge veya ülkeyle herhangi bir vatandaşlık bağının bulunmamasıdır (Malet, 2013:9). Ayrıca terörist savaşçılar ve profesyonel savaş şirketleri bu kavramsallaştırmaya dâhil edilmemiştir. Malet yabancı savaşçılar olgusunun kavramsallaştırması noktasında önemli katkılar sağlamasına karşın kavramın bazı boyutlarını görmezden gelmiştir. Örneğin, çifte vatandaşlık durumunda olan yabancı savaşçıların bu kavramın tam olarak neresinde olduğu cevaplanamayan soruların başındadır.

Diğer yandan daha genel bir kavramsallaştırma üzerinden Bryan (2010:115) yabancı savaşçıları evlerinden uzakta ulus ötesi bir dava ya da kimlik için savaşanlar olarak tanımlarken, Moore ve Tumelty (2008:412) ise "maddi imkânlardan ziyade dini, akrabalık ilişkilerinden veya ideolojik nedenlerden dolayı harekete geçip savaş bölgelerine giren, yerleşik olmayan ve topraksız savaş̧̧ıları" kapsadığını ileri sürmüştür. Bu yaklaşım diğer tanımların aksine yabancı savaşçı kavramını devlet dışı aktörler ve direniş gruplarının ötesinde görme eğilimindedir.

$\mathrm{Bu}$ yaklaşımlara paralel olarak, yabancı savaşçılar olgusunu çalışan Thomas Hegghammer yabancı savaşçıların 4 özelliği olduğundan bahsetmektedir. Ona göre yabancı savaşçıların direniş gruplarına katılması ve belirli sınırlar içerisinde faaliyet göstermesi, çatışmanın yaşandığı ülkeye herhangi bir vatandaşlık bağı ile bağlı olmaması, herhangi bir resmi askeri birliğe dâhil olmaması ve eylemleri için herhangi bir ücret talep etmemesi gerektiğini vurgulamıştır (Hegghammer,2010: 57-58). İlk başlarda Malet'in kavramsallaşması ile büyük oranda benzerlik göstermesine karşın daha sonra yaptığı başka bir tanımda ise Malet'in diasporalar ve akrabalık noktasında gösterdiği eksikliği gidermiştir. Diaspora kimliği ve akrabalık bağı böylelikle yabancı savaşçılık tanımına dâhil edilmiştir (Hegghammer, 2013:1). Hegghammer'ın da kavramsallaştırması daha çok Müslüman coğrafyalarda yaşanan çatışma analizinden doğmuş ve uluslararası terörist faaliyetler olgusuna dikkat çekerek, yeni durumun yabancı savaşçı kavramından ayrılması gerektiğini iddia ederek, başka bir tartışmanın fitilini ateşlemiştir. Savaşılan bölge dışında savaşla ilgisi olmayanlara yönelik olarak bir şiddet eyleminde bulunulması durumunda, yabancı savaşçı teriminin kullanılmaması gerektiğini söylemektedir. Mevcut literatürden anlaşıldığı üzere yabancı savaşçı kavramı Birleşmiş Milletler Güvenlik Konseyi (BMGK) kararına kadar daha çok Müslüman coğrafyalarda yaşanan çatışmalarla ilişkilendirilmiştir. $\mathrm{Bu}$ bakış açısı kavramı kısa süre içerisinde cihat bölgelerinde eğitim almak ve gayri-Müslim gruplara karşı çatışmak için yerleşik bulundukları batı ülkelerinden ayrılarak şiddete varan aşırıcılık eylemlerinde bulunanları kapsayan batı merkezci (eurocentric) bir kavram haline dönüşmüştür.

Ayrıca Sünni İslam'a bağlılık yabancı savaşçı kavramının çekirdeğini oluşturan özelliklerden biri olmuştur (Rich ve Conduit, 2014: 114). İlk dönem 
kavramsallaştırma çabaları içerisinde Müslüman kimlik ve yabancı savaşçı olgusu arasında sıkı bir bağ kurulmaya çalışılırken tarihi süreçte farklı kimlikler ve motivasyonlar sonucu ortaya çıkmış yabancı savaşçılar neredeyse hatırlanmamaktadır. Belirtmek gerekir ki dünyanın doğu yarım küresinden gelen militanlar ise bu kavramsallaştırmaya dâhil edilmemiştir. Bu durum kavramın tüm boyutlarıyla değerlendirilmesinin önüne geçmektedir. Fakat bu düşüncenin aksine ulus ötesi isyanlar olgusu çalışılırken "yakın ve uzak" yabancı savaşçı kavramları arasında bir ayrım yapılması kavramın derinliğinin anlaşılmasına yardımcı olabilir. Yakın yabancı gönüllüler ideoloji ve davayla daha fazla özdeşleşirken aynı zamanda etnisite ve dil gibi ek ortak bağlara sahip olabilmektedir. Uzaktan katılan yabancı savaşçılara oranla katılım hacimleri ve asimilasyon dereceleri daha yüksek düzeydedir (Hatahet vd, 2019: 7-8).

Her ne kadar literatürde batılı yazarların yabancı savaşçılar için geliştirdikleri kavramsallaştırmaların ağırlığı hissedilse de alternatif tanımlara da rastlamak mümkündür. Örneğin, Oktay Bingöl yabancı savaşçıları;

"çatışan taraflardan birinin vatandaşı olmayan, taraflardan birine savaşmak, şiddet eylemlerine başvurmak, bu amaçla eğitim vermek ve almak, diğer usullerle destek sağlamak için katılan; bireysel, etnik, dinsel ve ideolojik amaçlar ile maddi ve örgütsel çıkarların değişken etkileşimleri ile hareket eden; çoğu durumlarda devletlerin örtülü istisnai durumlarda açık kontrolünde ve yönlendirmesinde faaliyet gösteren kişiler"

olarak tanımlamaktadır (Bingöl,2016:4).

Diğerlerinden farklı olarak Bingöl, yabancı savaşçlar ve paralı askerler arasındaki sınırın çok net olmadığını, Batı ülkelerinden yabancı savaşçıların önemli bir kısmının daha önce ordularda para karşılığı görev yapmış kişiler olduğunu belirtmektedir (Bingöl,2016:5). Maddi beklentiler amaciyla yabancı savaşçılar içerisine katılan bir grup yabancı savaşçı kavramını farklı bir boyuttan değerlendirmeyi zorunlu kılmaktadır.

Görüldüğü üzere yabancı savaşçı olgusunun dinamik ve değişken özelliği 2011'de başlayan Suriye iç savaşıyla beraber bölgedeki yaşanan gelişmelerden etkilenmiş ve yeniden tanımlanmak zorunda kalmıştır. Özellikle bölgede 2013 tarihinden itibaren terör gruplarının aktif olmaya başlaması, Suriye iç savaşındaki aktörlerin artmasına ve savaşın çok boyutlu ve çok aktörlü bir şekle evrilmesine yol açmıştır. Aynı zamanda bölge üzerinde siyasi projeksiyonlar geliştiren uluslararası aktörler, Irak Şam İslam Devleti'nin (IŞiD) eylemlerini ayrı bir zeminde değerlendirmeye ve yabancı savaşçı olgusundan ayırmaya itmiş̧ir. ${ }^{2}$ IŞiD’e katılanlar doğrudan terörizm çatısı altında görülmüştür. Çünkü geleneksel olarak yabancı savaş̧̧ılar çoğu zaman gönüllülük esasına göre mevcut düzenli orduların yanında savaşmıştır. Kavramın önündeki karmaşayı ve muğlaklığı ${ }^{2}$ Makale boyunca kavram ilk çıktığı şekliyle kullanılmıştır. Zaman içerisinde siyasi literatürde
Daeş/Daesh kavramının da kullanıldığı görülmektedir. 
gidermek maksadıyla BMGK 2178 sayılı kararı yabancı terörist savaşçı kavramını uluslararası ilişkilerin gündemine sokmuştur. BMGK

"kendi devletleri dışındaki bir devlete terörist eylemleri işlemek, planlamak, hazırlamak ya da katılmak için giden bireyler veya silahlı çatışmayla bağlantılı olmak da dâhil, terörist eğitim alan ve veren bireyler" olarak yabancı terörist savaşçıları tanımlamış ve terör konusunda devlet liderlerinin ortak bir zeminde buluşmasına yol açmıştır (BMGK, 2014).

Fakat BMGK'nın bu çabasının başarılı olduğunu söylemek zordur. Çünkü yaptıkları yeni tanım yabancı savaşçı ve yabancı terörist savaş̧̧ı olgularını tam olarak kapsamamaktadır. Çünkü kavramın kullanılmaya başlandığı günden itibaren sadece IŞiD'liler ya da diğer radikal İslami grupları tanımlamak için kullanılmaktadır. Dolayısıyla diğer motivasyonlarla (sol ideoloji, etnik, macera ya da Hristiyanlık) bölgeye gelen aşırıcılar bu kapsam içinde değerlendirilmemiştir. Açıkça iddia edilebilir ki BMGK'nin bu tanımı aslında üzerinde uzlaşılan bir terörizm tanımı olmadan yabancı savaşçı olgusunu daha karmaşık haline getirmiştir (Malet, 2015:458). Çünkü her ülke yabancı terörist savaşçı olgusunu kendine göre yorumlama yoluna gitmiştir.

Bob Crow Tugay1, Henri Krasucki Tugayı, Halkların Birleşik Devrim Hareketi veya Birleşik Özgürlük Güçleri gibi grupların Suriye'deki faaliyetleri iyi bir biçimde analiz edilirse en az IŞiD kadar bölgenin istikrarının bozulmasına yol açtıkları görülebilir (Hatahet vd, 2019: 21-33). Bu durum aslında tamamen ülkelerin güvenlik algıları ile ilgilidir. Konstrüraktif politika yapım sürecinde Batılı devletler öncelikli olarak IŞID, El-Nusra ve El-Kaide gibi örgütleri ve bunlara katılan gönüllüleri tehdit olarak algılamaktadır. Yabancı terörist savaşçı kavramının başlıca örgütleri kapsaması normaldir. Fakat her ülke güvenlik algısını farklı biçimlerde inşa edebileceği için Türkiye'nin de içinde olduğu bölge ülkeleri açısından bu örgütlere ek olarak YPG-PKK gibi başka güvenlik tehditleri de mevcuttur. Dolayısıyla yabancı terörist savaşçı kavramı kullanılırken Bingöl'ün de ifade ettiği gibi terör örgütleri arasında ayrım gözetmeden kullanılması gerekmektedir (Bingöl, 2016: 4). Fakat pratikteki uygulamaya bakıldığında kavramın kullanılması tamamen farklılaşmaktadır. Suriye İç Savaşında aktör haline dönmüş olan etnik-sol gruplar, birçok Avrupa ülkesinde terör grubu olarak kabul edilmemektedir. Ayrıca BMGK'nin söz konusu kararı ulus ötesi savaşın konuşulduğu ve çok aktörlü iç savaşların yaşandığı çağımızda kavramın bütün boyutlarını ortaya koymakta başarısız olduğu açıktır. BMGK'nın kararıyla kimin terörist, kimin yabancı kimin ise savaş̧̧ oluğu oldukça tartışmalı konular haline dönüşmüştür (Özdemir ve Aksu, 2018: 1190). ${ }^{3}$ Özellikle yabancı tanımı her ne kadar (en yalın haliyle) vatandaşlığın zıttı olarak düşünülse de çifte vatandaşlık ve diasporik kimlikler (hibrit bir şekilde) yabancı kavramını muğlaklaştırmaktadır. Farklı bir biçimde ifade edilirse kişi vatandaşlık bağı ile bağlı olmamasına ve hukuken yabancı sayılmasına karşın, sahip olduğu sosyal

${ }^{3}$ Iran milisleri literatürde YTS ya da YS kavramları bünyesinde sayılmamaktadır. 
kimlikler aracılığıyla kişi kendisini o ülkedeki insanlardan farklı görmemekte ve aynı ortak potada buluşabilmektedir. Benzer şekilde savaş̧̧ kavramı da tartışmalıdır. Bazı ülkeler savaşçı tanımını dar anlamıyla yorumlayarak doğrudan muharip gücü kastetmektedir. Fakat bölgede en az muharip güç kadar lojistik destek vermek amaciyla bulunan kişiler de mevcuttur. Bu kişiler kimi zaman çocuk doğurarak kimi zaman propaganda yaparak bu terör eylemlerine ortak olmaktadır. Dolayısıyla savaşçı terimini dar anlamda yorumlamak yabancı savaşçı olgusunun anlaşılmasını zayıflatan bir yaklaşım olarak düşünülebilir.

Yabancı savaşçı ve yabancı terörist savaşçı terimleri üzerine kavramsal tartışmalar sürmesine ve uzlaşılan bir tanımının henüz ortaya çıkmamasına karşın Suriye iç savaşı kapsamında bu olguyu farklı bir temelde tartışmak mümkündür. Özellikle kimlik temelli bir yaklaşımla savaşçıları dini ve seküler kimliklerine göre iki ana gruba ayırmak mümkündür. IŞID, El-Kaide, El-Nusra Cephesi ve YPG gibi gruplar yabancı teröristlere/savaşçılara ev sahipliği yapmaktadır. Her ne kadar bu gruplar motivasyon, savaş becerileri, ittifakları ve paylaşılan kimlikleri açısından gözle görülür biçimde farklılıklar taşısa da iki noktada benzerlik göstermektedirler. İlk benzerlik savaşçı devşirmede kullandıkları modellerdir. Byman ve Shapiro (2014:7) önceki örneklerden yola çıkarak 5 aşamalı şematik bir model üzerinden yabancı savaşçı olgusu anlaşılabileceğini ileri sürmüşlerdir. Bu modele göre tüm yabancı savaşçılar ilk olarak karar verme sürecini deneyimler. Bu karar verme sürecinde çatışma bölgesiyle kendileri arasında farklı temellere dayanan ilişkiler kurarak ortak bir paydada buluşmaya çalışırlar. Daha sonra ise çatışma bölgesine giderek ve eğitim sürecini tamamladıktan sonra çatışma sürecine dâhil olurlar. Dördüncü aşama ise eve dönüş süreci olarak da bilinen savaş̧̧ıların uyruğu olduğu ülkelere dönmesidir. Çatışma bölgelerinde edindikleri deneyimleri çatışma dışı bölgelere taşımaları açısından önemli bir evredir. Son aşama ise yerel saldırılar planladıkları aşamadır. Bu model izlendiği takdirde hem dini motifleri kullanan IŞiD hem de sol ve etnik motifleri kullanan YPG'ye katılanların benzer süreçleri izledikleri anlaşılabilir (Birleşmiş Milletler Terörle Mücadele Ofisi [UNCTO], 2017; The Soufan Group, 2015; Hatahet vd, 2019).

Modelleme açısından gözlemlenen benzerliğe ek olarak hem dini hem de etnik-sol motifli örgütler Suriye'de ve Ortadoğu bölgesinde istikrarsızlık ve belirsizliklerin artmasına katkı sağlamaktadır. Bu grupların savaşa müdahil olmaları ya da terör gruplarına eklemlenmeleri iç savaşın uzamasına, farklı yönlere evrilmesine ve savaşa dâhil olan aktör sayının artmasına yol açmaktadır. Bölgenin istikrarsızlaşmasına yönelik faaliyetleri büyük oranda benzerlik göstermektedir.

\section{Bölgedeki Faaliyetleri}

2011'den itibaren değişen aralıklarla uluslararası örgütler tarafından yayımlanan raporlar dikkatle analiz edildiği takdirde bu terör örgütlerinin (dolayısıyla yabancı savaş̧̧ıların) faaliyetlerini "sivil hayata yönelik, demografik 
ve sosyal yapıya yönelik ve devşirilen çocuk savaşçılar" olmak üzere üç başlık altında toplamak mümkündür.

İlk olarak sivil hayata yönelik faaliyetlerine odaklanıldığında her ne kadar sahip oldukları motivasyon ya da ideolojiler farklı da olsa iki grubun benzer politikalar uygulamaya çalıştığı anlaşılmaktadır. Öteki olarak algıladıkları gruplara yaşama şansı tanımamaktadır. Örneğin, mevcudiyetini tamamen ElKaide ve Taliban gibi örgütlerde olduğu gibi Selefilik düşüncesi üzerine inşa eden IŞİD, Batı karşıtlığı, dini fanatizm ve terör metotlarını kullanarak önce Irak daha sonra ise Suriye'de merkezi otoritenin ortadan kalkmasiyla Suriye coğrafyasında etkili olmaya başlamıştır (Erdoğan ve Deligöz, 2015:13).

IŞID eylemlerini meşrulaştırmak için İslam dinini kullanmaktan çekinmemiş, yaptıkları savaşın Bağdadi’nin kendi sözleriyle “...Hiç kimse, başlattığımız savaşın İslam Devleti’nin savaşı olduğuna inanmamalı. Bu tüm Müslümanların savaşıdır, İslam devleti de bu savaşa öncülük ediyor. $\mathrm{Bu}$ Müslümanların kâfirlere karşı savaşıdır" olduğunu beyan etmiştir (BBC Türkçe, 2015). Batı'da yaşayan Müslümanların çağrıya destek vermeleri örgütün kısa bir süre içinde uluslararası toplumun güven istikrarını tehdit eden bir yapıya dönüşmesini hızlandırmıştır. Özellikle Batılı ülkelerden IŞiD'in sözde lideri Bağdadi'nin hicret çağnısına uyan binlerce insan Suriye topraklara göç etmiştir. Sahip olduğu ideoloji ve finansal güç özellikle umutsuzluğa kapılmış kitleler için umut kaynağı olurken, yabancı savaşşıların bölgedeki varlıklarının pekiş̧irilmesinde ve güç boşluklarının doldurulmasında etkili olmuştur (Gülşen, 2019:14). IŞID kontrol ettiği bölgelerde primative eylemlerine ek olarak diğer terör gruplarından farklı olarak ele geçirdikleri toprakları yönetmeye diğer bir deyişle devlet kurmaya çalışmıştır (Karabat, 2014). Aslında sivil hayata yönelik baskıların birçoğu ideolojilerinde açıkça belirtikleri "dünyevi cennet" in sonuçlarıdır. Sinan Hatahet'in belirtiği üzere IŞSiD "açık" ve "basit olma" şeklinde iki kutuplu bir vizyona sahip olarak, zahirî fikıh anlayışına dayanarak bir yandan sert cezalar ile Müslüman yerel halkın bunalmasına diğer yandan gayri-Müslim azınlıklar da dâhil olmak üzere mürtetlere karşı acımasız politikalar izlemesine rağmen, kontrol ettiği yerlerde "hukuk ve düzeni" yeniden sağlamıştır (Hatahet, 2015:5-6). Bu düzen içinde kolluk kuvvetleri, mahkemeler, eğitim ve yönetim kurumları sivil hayatı baskı altına alan aygıtlara dönüşmüştür.

İnsan Hakları Konseyi’nin 2014 yılında yayınladığı rapora göre hâkimiyet kurulan bölgelerde yaşayan kadın, erkek ve çocuklar gündelik hayatlarının idaresinde yoğun bir korku altında yaşamaktadır. Etnik ve dini azınlıklar ya asimile olmak ya da bölgeden kaçma zorunda kalırken Müslüman halk ise IŞiD'in din adına çizdiği ideolojik prensipleri kabul etmeye mecbur bırakılmıştır. Kendi kurallarının yerleşmesi ve "ibret" olması adına tüm cezalandırmalar vahşi bir şekilde meydanlarda gerçekleşmiştir. Ayrıca tüm infazlar kayıt altına alınmıştır. Bunlar daha sonra propaganda malzemesi olarak kullanılmıştır. Müslüman olmayanlardan cizye alınmaya başlanmış ya da zorla din değiştirmeler yaşanmıştır (UNHRC, 2014:4-10). Raporda belirtiği gibi hiçbir şekilde 
eğlencelerin, düğünlerin veya geleneksel seremonilerin icra edilmesine izin verilmemiştir. Sosyal ve kültürel pratikler gündelik hayattan silinmiştir (UNHRC, 2014:4). Kamusal alan keskin bir biçimde yeniden tanımlanırken kadınların bu alana dâhil olması yasaklanmıştır. Kadın ve erkeklerin doğrudan görüşmeleri yasaklanırken, yanlarında erkek olmadan kadınların tek başlarına dışarı çıkmaları engellenmiştir. Bu kurallara uymayanlar ise şiddetli biçimde cezalandırılmıştır (Codexter, 2016: 8-10). Örneğin, diş hekimi Rou'aa Diab 17 Ağustos 2014 tarihinde Suriye'nin Der-i Zor bölgesinde erkek hastaları da tedavi ettiği gerekçesiyle herhangi bir yargılama yapılmadan IŞiD militanları tarafindan infaz edilmiştir. Onun ölümü IŞiD'in sosyal hayat üzerindeki baskı politikalarına verilebilecek trajik örnekler arasındadır (Almasdarnews, 2014).

Müslüman olmayan kadın ve çocuklar ise çok daha vahşi uygulamalara maruz kalmıştır. Özellikle IŞİD'in ele geçirdiği yerlerde Yezidi kadınlar köle olarak pazarlarda satılmıştır (defandinternational.org, 2015; Codexter, 2016: 1013). İnsan Hakları İzleme Örgütü'nün 2016 tarihindeki raporlarına bakıldığında IŞiD'in elinde 1800 kadar Yezidi kadın ve çocuğun köle olarak tutulduğu bilgisi görülmektedir (İnsan Hakları İzleme Örgütü [HRW], 2016). ${ }^{4}$ IŞİD'in uyguladığı bu vahşet kısa sürede bölgedeki güven ve istikrar ortamını kaldırırken, kitlesel göç hareketlerini hızlandırmıştır. Davis'in belirttiği üzere 2014 yılında başlayan göç dalgasının özelliklerinden biri "cihatçı şiddet" ve terör eylemleri sonucunda oluşmasıdır. Sadece Eylül ve Ekim ayında IŞSiD'den kaçan 190 bin Suriyeli Türkiye sınırını geçmiştir (Davis, 2015: 70). Zaten UNHRC'nin de açılamalarına odaklanıldığında 2014 yılının dünyada göç sayısının en fazla arttığı yıl olduğu görülmektedir (UNHRC, 2014).

Diğer yandan bölgede faaliyet gösteren başka bir terör örgütü olan YPG ve onun yabanc1 savaşçıları da siviller üzerinde bask1 uygulamaktan çekinmemişlerdir. Belki eylemleri IŞSiD'inki kadar propagandist biçimde görülmemektedir. Fakat sivil halk üzerinde sistematik bask1 mekanizması kurmuşlardır. İnsan Hakları İzleme Örgütü’nün ve Uluslararası Af Örgütü’nün raporlarında sıklıkla ifade edildiği üzere YPG elindeki silahlı gücü, öncelikle IŞiD'den kurtarılan yerlerdeki yerel halk üzerinde ve muhaliflerin susturmak amacıyla kullanmıştır. Örneğin, Afrin'de Hanan Hamdosh isimli sivilin gözaltında öldürülmesi raporda bahsedilen YPG'nin işlediği suçlar arasındadır. Dügünün ertesi günü Hamdosh, PKK elebaşı Abdullah Öcalan ve PKK'ya hakaret ettiği için gözaltına alınmış ve nezaretten bir daha çıkamamıştır. YPG, Ocak 2014'de yürürlüğge giren Sosyal Kontratın 25. maddesine de aykırı davranmıştır (HRW, 2014: 28). YPG kısa bir süre içerisinde fiziki ve mental şiddet yöntemleriyle 1651 kişinin hayatını kaybetmesine yol açmıştır. 27-28 Haziran 2013'de gerçekleşen Amuda protestolarında sivil halk üzerine ateş açmaktan çekinmemiş, 4 kişinin ölümüne ve onlarca kişinin ise yaralanmasına

${ }^{4} H R W$ tarafindan yakın dönemde yayınlanan raporda belirtiği üzere Irak'ta Yezidi kadın ve çocuklara karşı uygulanan suçlardan kimse yargılanmamıştır (HRW, 2020). 
sebep olmuştur. Ayrıca zorunlu askerlik uygulaması başlatarak kadın ve çocukların YPG saflarına katarak, cephelerde aktif bir çatışmaya girmelerine neden olmuştur (HRW, 2014: 26-30). Suriye İnsan Hakları Ağı raporuna göre YPG bölgede 146 kişiyi öldürürken 673 kişiyi ise gözaltına almıştır (Suriye İnsan Hakları Ağ1 [SHNR], 2016:40-41).

Diğer yandan demografik ve sosyal yapı üzerinde de yabancı savaşçılardan oluşan bu iki örgütün benzer yöntemler kullandığ 1 görülmektedir. $\mathrm{Bu}$ yöntemlerden en bilineni yerleşik nüfusun baskı kimi zaman ise etnik temizliğe maruz bırakılarak bölgenin boşaltılmasıdır. IŞiD Suriye topraklarında gücünü artırdığı dönemde Arap olmayan halka yönelik kitlesel göç dalgasının ortaya çıkmasına neden olmuştur. 2013 tarihinde Rakka ve Tel Abyad'ın ele geçirilmesi üzerinde çok sayıda Kürt ve Türkmen nüfus bölgeden ayrılmak zorunda kalmıştır. Kalan mallar IŞ่iD savaş̧̧ıları tarafından yağmalanmış ya da bazı durumlarda Suriye'nin Qalamoun ve Dayr Az-Zawr bölgelerinden getirilen Sünni Arap aileler yerleştirilmiştir (UNHRC, 2014: 5). Ek olarak bölgedeki fiziki yapı ve kültürel miras da talan edilmiştir. Şii camiler, köyler ya da Sünni nüfusa ait türbeler "bi'dat" oldukları gerekçesiyle yok edilmiştir. Şam civarındaki Duma'da bulunan âlim mezarları, Dabık'da bulunan Türkmen köyü ve mezarlıkları, Kamışlı'da bulunan Nakşibendi şeyhlerinin mezarları yok edilerek, Türk-İslam dünyasının hafızası hedef alınarak ve sadece toprağın üstündeki insanlar değil altındaki kişiler de IŞiD zulmüne maruz kalmıştır (Demir, 2019; UNHRC, 2014:6). Benzer bir şekilde YPG de IŞID sonrası bölgede aynı politikaları izlemiştir. Uluslararası Af Örgütü'nün raporunda bahsedildiği üzere etnik temizlik politikası benimsenmiş ve boşaltılan köylere bu sefer Kürt nüfus yerleştirilmeye çalışılmıştır. Ele geçirilen bölgelerin isimleri değiştirilmiş hatta kimi zaman köyler tamamen yok edilmiştir (Amnesty International, 2015). SNHR 2015 raporuna göre 9 köy yıkılmış, 19 köy ise kısmen tahrip edilmiştir. On binlerce kişi ise bölgeden kaçmak zorunda kalmıştır. Örneğin Şubat 2015'te bölgenin yerli nüfusu olan Türkmenler Heseke bölgesinden kaçarak Türkiye'ye sığınmıştır. Böylelikle bölgenin olası barış görüşmeleri sırasında Kürt toprakları olarak anılmasına yol açmışır. Bahsedilen raporlarda YPG tarafından açıkça uluslararası insan haklarının temel ilkelerinin ihlal edildiği belirtilmiştir.

Son olarak ise iki örgüt de çocukları militan olarak kullanmaktan çekinmemiştir. Birleşmiş Milletler Genel Sekreterliğinin çocuk ve silahlı çatışmalar üzerine hazırladığı 2019 tarihli raporda 18 yaşından küçük çocukların YPG saflarına katıldığı ve örgütün ayakta kalması ve personel ihtiyacını sağlamak için kullanıldıkları ifade edilmiştir (Birleşmiş Milletler [UN], 2019: 2627). Bu çocuklara hem çatışma bölgelerinde hem de kontrol noktalarında görevler verildiğinin altı çizilmiş̧ir. Ayrıca çocuk militanlar güçlü bir propaganda malzemesi olarak kullanılmıştır. Özellikle yabancı savaşçıları ve dış toplumu etkilemek için bu çocukların ne kadar kahraman olduklarının propagandası yapılmıştır. Birleşik Devletler tarafından (ABD'de) insan kaçakçılığı üzerine yayımlanan raporda 15 yaş altı çocukların cephelere götürüldüğü ve çocuk 
kaçırmaların yaygın olduğu raporun öne çıkardığı hususlardan bazılarıdır. (State, 2016: 358). IŞiD de benzer şekilde erkek çocuklarını yoğun bir doktrinasyon sürecinden geçirerek hem askeri hem ideolojik anlamda örgütün devam etmesi için çabalamıştır. Ergenliğe giren kız çocuklar ise savaş̧̧ıların eşleri olarak ailelerinin yanından kaçırılması bölgede evlenmemiş kızı olan ailelerin büyük bir korkuya kapılmasına ve genç kızlarını küçük yaşlarda evlendirmelerine yol açmıştır (UNHRC, 2014: 9).

$\mathrm{Bu}$ örgütlerin ve yabancı savaşçıların bölgedeki faaliyetleri değerlendirildiğinde uluslararası insancıl hukuk, insan hakları hukuku ve uluslararası savaş hukukunun temel ilkelerini ihlal ettikleri görülmektedir. Örneğin, orantısız güç kullanımı, çatışmalarda sivil halkın hedef alınması, yargısız infazlar, işkenceler, ölümcül cezalandırmalar, sivillerin kalkan olarak kullanılması, yerinden etmeler, sürgünler ve gücün kötüye kullanılmas1 gibi eylemler, insan hakları hukukunun temel ilkelerini ${ }^{5}$ ihlal etmektedir (UNHRC, 2017: 17-21).

\section{Uyruğu Olduğu Ülkelerdeki Sorunlar}

Yabancı savaşçılar/yabancı terörist savaşçılar olgusu kapsamında üzerinde durulması gereken diğer bir mesele bu savaşçıların geri dönüşleri ve sonrasında ortaya çıkması muhtemel sorunlardır. Yabancı savaşçılar üzerine gelişen literatürden anlaşıldığı üzere, yabancı savaşçlık olgusu genellikle üç şekilde son bulmaktadır. Yabancı savaş̧̧ının çatışma bölgesinde ölmesi, çatışma bölgesinden ya uyruğu olduğu ya da üçüncü bir ülkeye ayrılması şeklinde gerçekleşmektedir. İkinci ve üçüncü seçenekler yabancı savaşçının başka bir terör eylemine karışması ya da barış̧̧ıl biçimde entegre olması aşamalarıyla detaylandırılabilmektedir. Çatışma bölgesinden ayrılanlar özellikle uyruğu olduğu ülkeler ve uluslararası güvenlik için yeni açmazlar ve sorunlar ortaya çıkarabilmektedir. Çünkü bu süreçte yabancı savaşçıların döndükleri ülkelerde yeniden terör saldırılarında bulunma şüphesi veya radikalleşen bireylerin toplumdaki diğer birey ve grupları etkileyebilme olasılıkları ülkelerin kapsamlı özel politikalar geliştirmelerini zorunlu hale getirmektedir (Zuijdewijn ve Bakker, 2014:10).

${ }^{5}$ Bu eylemlerin İnsan Hakları Evrensel Beyannamesinin 4, 5 ve 9.ncu maddelerini açıç̧a ihlal ettiği anlaşılmaktadır. 


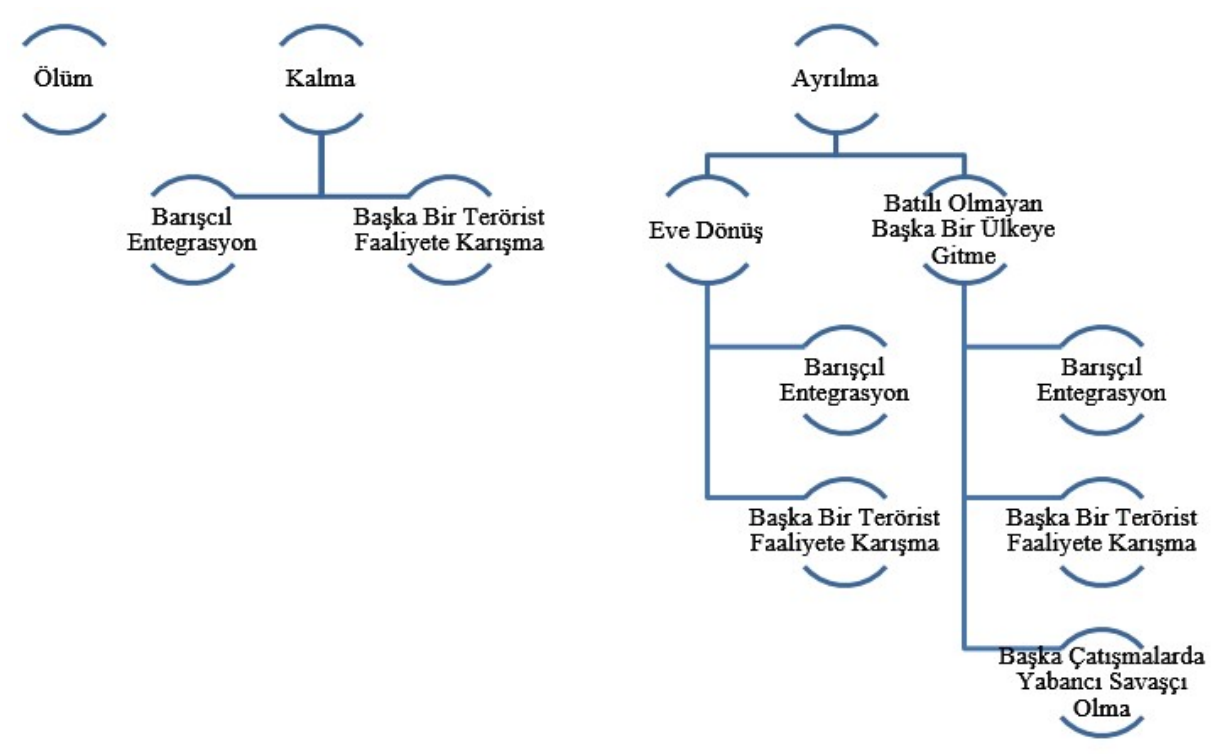

Şekil 1: Yabancı Savaşşıların Gidişatını gösteren diyagram Zuijdewijn ve Bakker'ın çalışmasından alınarak Türkçeleştirilmiştir.

Geçmiş dönemlere nazaran yabancı savaşçılar hakkında daha fazla somut bilgiye sahip olmamıza karşın bunların ortaya çıkaracakları muhtemel sonuçlar hala muğlaklıklarını korumaktadır. 2011'de başlayan Suriye iç savaşı ve sonrasında dini ve etnik motifli terör örgütlerinin bölgede hâkimiyet kurma çabaları bölgeye savaşçı göçünün başlamasına yol açmıştır. 2017 yılında Radikalleşme Bilinç Ağı tarafından yayımlanan raporda 2011 ve 2016 yılları arasında 120 ülkeden yaklaşık olarak 42000 yabancı savaşçının bulundukları ülkeleri terk ederek çatışma bölgelerine gittiği gerekli olan eğitimleri aldıktan sonra IŞiD'in küresel koalisyon karşısında yenilgisine kadar bölgeyi terörize ettikleri belirtilmektedir. Fakat 2015 y1lı itibariyle geri dönüşlerin başladığı gözlenmiş̧ir. Savaş̧̧1ların büyük çoğunluğunun geri döndüğü, sadece Avrupa Birliği (AB) içine 5000'den fazla savaşçının döndüğü tespiti raporun önemli bulgularındandır (Radikalleşme Bilinç Ağı [RAN], 2017:6; Barrett, 2017:7-8).

Geri dönenler üzerine yapılan araştırmalar bu geri dönüş eğiliminin birbirinden farklı amaçlarla gerçekleştiğini göstermektedir. Kadın, erkek ve çocukların da geri dönmesiyle nedenler 4 ana başlıkta toplanabilmektedir. Bunlardan ilki savaşçıların aldandıklarının/gözlerinin boyandıklarının farkına varmasıdır. Diğer bir neden ise daha iyi koşullarda yaşama istekleridir. Raporda bu tip savaşçılar firsatçı olarak etiketlenirken, ideolojik olarak aynı ilkeleri paylaşmaya devam ettikleri vurgulanmıştır. Dönenler arasında üçüncü bir grup ise sahip oldukları çatışma deneyimlerini başka sahalara da yayma ve yeni terör eylemleri gerçekleştirme arzusunda olanlar olarak kategorize edilmiştir. Son grup ise yakalananlar ve isteksiz biçimde uyruğu olduğu ülkeye iade edilenlerdir 
(RAN, 2017:9). Bu sınıflandırma daha çok IşiD'e katılan savaşçılar için geçerli olsa da etnik ve sol güdülerle bölgeye gelip YPG saflarına katılan yabancı savaşçıları da unutmamak gerekir. YPG içerisindeki yabancıların sayısı daha çok kişisel kontaklarla elde edilen bilgilere ve tahminlere dayanmaktadır. İddialardan birisi bu sayının 800'e kadar çıktığıdır (Hatahet vd, 2019:9). Fakat Orton'un çalışmasında net sayılardan bahsedilmemesine karşın YPG içerisinde 12 ülkeden katılımın olduğu ifade edilmektedir. (Orton, 2017:116-117).

Dolayısıyla yabancı savaşçılar hakkında elimizde olan bilgilerden anlaşıldığı üzere, savaşçıların geri dönüşleri başta $\mathrm{AB}$ ülkeleri olmak üzere tehditler içermektedir. Potansiyel tehdit düşüncesinin arkasında yatan geri dönen savaşçıların "geri tepme" olasılığıdır. Geri tepme en kısa tanımıyla çatışma bölgesinden ayrılanların evlerinde ya da başka bir ülkede terör eylemlerine müdahil olmasıdır. Diğer bir deyişle çatışma ve istikrarsızlık durumunun başka coğrafyalara kolaylıkla yayılmasıdır. Dolayısıyla, ülkeler açısından yabancı savaşçıların geri dönüşü atlanmaması gereken güvenlik meselelerinden biri olarak düşünülmektedir. Geçmişe kıyasla yabancı savaşçılar çok daha küresel bir ağ kullanmaktadır. Çatışma bölgesinden dönmelerine karşın oradaki bağlarla iletişimi kesmeyebilir, çatışmanın olmadığı bölgelerde hem propaganda faaliyetlerinde hem de uyuyan hücreler konumunda kalabilirler. Farklı biçimde ifade edilirse çatışma ve silah kullanma tecrübesine sahip yabancı savaşçılar kazandıkları deneyim ve bağlantıları Avrupa içlerine kadar sokabilir ve terör örgütlerinin yeni mevziler ve teşkilatlanmalar kazanmasına yol açabilir. Hegghammer' in veri setinden anlaşıldığı üzere yabancı savaşçıların "geri tepme etkisi" yani başka bir terör suçuna karışma olasılığı yüksektir. Geri dönen savaşçılarının ölümcül ve yüksek oranda başarılı olma olasıllğı yüzde 67'ye kadar ç1kabilmektedir (Hegghammer, 2013: 6).

$\mathrm{Bu}$ olasılık $\mathrm{AB}$ ülkelerinin güvenlik politikalarında yabancı savaşçılarla nasıl mücadele edecekleri konusunda farklı yaklaşımlar benimsemelerine yol açmaktadır. $\mathrm{Bu}$ yaklaşımlardan ilki yabancı savaşçıları bölgede yaptıkları eylemlerden dolayı cezalandırmayı amaçlayan sert yaklaşımdır (Boutin, 2016). Ülkelerine dönene savaşçlların bölgedeki faaliyetleri büyük oranda terör suçu kapsamında değerlendirilmekte ve cezaların caydırıcıllı̆ı ve kapsamı tartışmalı olmasına karşın ceza yargılamalarına konu olabilmektedir. Bu yaklaşım başta Belçika olmak üzere bazı $\mathrm{AB}$ ülkeleri tarafından tercih edilmektedir (Gülşen, 2019: 19). Belçika örneğine odaklandığımızda IŞī'e 528 vatandaşının katıldığı bunlardan 123 'ünün geri döndüğü ve 275 kişinin ise bölgede kalmaya devam ettiği bilinmektedir. Belçika sınırda yakalananlar ve geri dönenler BMGK'nın 2178 sayılı kararı ve AB'nin terör yönergelerini baz alınarak geri dönenler terör suçları kapsamında yargılanmaya başlanmıştır. Bu bağlamda Belçika, sadece terör eylemine doğrudan katılanlar değil, bir terör örgütüne katılmak amacıyla yabancı bir ülkeye seyahat etmek, terörist eğitim vermek ya da almak veya terör örgütüne finansal destek sağlamayı da bir terör suçu olarak kabul etmektedir (Barlett, 2017: 12; Gülşen, 2019: 19). Diğer bir yaklaşım ise daha çok 


\section{Suriye İ̧̧ Savaşında Yabancı Savaşşılar}

rehabilitasyon sürecini öne çıkararak savaşçıları topluma başarılı bir şekilde yeniden entegre etmeyi amaçlamaktadır. Dolaysıyla verilen hapis cezaları yaklaşık olarak 4 sene civarında olmaktadır (Raudszus, 2020). Fakat bu yaklaşımların şimdiden ne kadarının başarılı olacağını tahmin etmek zordur. Başarı şanslarının düşük olduğu ve ciddi maliyet getirdiği sıklıkla telaffuz edilmektedir. Örneğin, Fransa' daki entegrasyon programının başarısız olmasının ardından yapılan eleştiriler daha çok rehabilite edilecek grubun doğru seçilmediği ve boş yere 2.5 milyon Euro harcanması olarak özetlenebilir (Reed ve Paul, 2017).

Fakat iki yaklaşımda da belirgin olmayan noktalar mevcuttur. Bunlardan ilki yabancı savaşçılar terör suçları kapsamında değerlendirilse bile faaliyetlerin ne kadarından sorumlu tutulacağ 1 açık değildir. Sert yaklaşımı benimseyen Belçika yargılama kararlarını BMGK'nın ve AB Konseyi'nin kararlarına dayandırarak taviz vermeyeceğini göstermiştir. Muharip güç dışında kalanlar da savaşçı ve terörist kategorisinde değerlendirilmektedir. Açıkça belirtmek gerekir ki savaşçı kavramını dar yorumlayarak cezai sorumluluklarının olmadığını düşünmek ya da bunları romantize etmek istikrara, barış ve güvenliğe katkı sağlamayacaktır.

İkinci belirsizlik ise yabancı terörist savaşçı ifadesinin hangi grubu kapsayacağı noktasıdır. AB ülkelerinin takip ettikleri yaklaşımlar ve uygulamaya çalıştıkları önlemler konusunda yabancı terörist savaşçı teriminin daha çok IŞiD'e katılanlar için kullanıldığ 1 anlaşılmaktadır. Çünkü YPG gibi terör örgütlerine katılanlar geriye döndükleri takdirde benzer uygulamalarla karşılaşmamaktadır. (Gülşen, 2019: 19). İngiliz vatandaş1 James Matthews Birleşik Krallık'a döndükten sonra terörle mücadele kanunu çerçevesinde tutuklanmış ama kısa bir sürede serbest kalmıştır (independent.co.uk, 2019). Üstüne üstlük propaganda faaliyetlerine devam etmektedir. "Lions of Rojava" ya da "Friends of Rojava" sayfası hala aktif olarak YPG propagandas1 yaparak bölgede YPG ve PKK'nın faaliyetlerini meşrulaştırmaktadır (Hatahet vd, 2019:34-35).

Uluslararası hukuk açısından yabancı savaşçıların yarattığı diğer sorun vatandaşlık uygulamalarında görülmektedir. Yabancı savaşçıların geri dönmesiyle bazı ülkeler, terör suçlarına karıştıkları gerekçesiyle vatandaşlık haklarını kaybettirme yoluna gitmektedir. Böylelikle kendi topraklarına yabancı savaşçı ve çocuklarını sokmamaya çalışmaktadır. Fakat uygulamaya baktığımızda bu durum beraberinde hem yabancı savaşçılar hem de tabi olunan devlet ve üçüncü devletler için önemli sonuçlar doğurmaktadır. Öncelikle her ne kadar vatandaşlığın kaybettirilmesi (ve buna bağlı olarak vatansız statüye düşmesi) devletin mutlak egemenliği altında görülmesine karşın uluslararası hukuk ve toplum tarafından çok arzulanan bir seçenek değildir. Bu durumu ortadan kaldırmak için bir dizi sözleşme mevcuttur. Bazı Vatansızlık Halleri Hakkında Protokol (1930), Birleşmiş Milletler Vatansızların Hukukî Durumu Hakkında Sözleşme (1954) ve Vatansızlık Hallerinin Sayısının Azaltılmasına 
Dair Sözleşme (1961) sözleşmeler uluslararası hukukta vatansızlıkla mücadele için kabul edilmiş temel belgelerdir. ${ }^{6}$ Vatansızlık uluslararası toplum tarafından ortak bir şekilde ortadan kaldırılmaya çalışılan bir sorundur. Dolayısıyla terör örgütlerine katıldıkları gerekçesiyle vatandaşlığın kaybettirilmesi daha sonra ülkeler aleyhine kullanılabilir. İngiltere bu durumu aşmak için çifte vatandaşlığı olup terör örgütlerine katılanların İngiliz vatandaşlıklarını düşürmektedir.

IŞiD gelini olarak bilinen Shamima Begum ve İngiliz vatandaşlığını kaybetme olayı İngiltere'nin yakın dönemde uluslararası toplumda tartışılan uygulamalarından biridir. Begum'ün aynı zamanda Bangladeş vatandaşı olması hasebiyle İngiliz vatandaşlığ 1 kaybettirilmiştir (BBC, 2020). İngiltere'nin bu yaklaşımı birçokları tarafından eleştirilmesine ve kararın temyiz sürecine sokulmasına karşın devlet egemenliği ve vatandaşın devlete karşı sorumluluğu çerçevesinden bakıldığında oldukça tutarlı ve anlamlı olduğu söylenebilir. Çünkü yabancı savaşçılar kimi zaman uyruğu olduğu ülkelerin hukuk kurallarına (radikalleşme ve terörizmi önleme konusunda) uymamışlardır. Örneğin, IŞiD’e katılan İngiliz uyruklu yabancı savaşçılar IŞSiD saflarında mücadele ederken sadece mevcut Suriye rejimine karşı mücadele etmemiş aynı zamanda 2014 yılında kurulan uluslararası koalisyon ve BMGK'nın ilgili hükümlerine aykırı hareket etmiştir. Basit bir biçimde ifade edilirse Bağdadi'nin çağrısına uymasıyla vatandaşı olduğu ülkesine karşı da savaşmıştır. ${ }^{7}$ Kimi zaman vatandaşlıktan çıkarmalar sorumluluktan kaçma olarak algılanmaktadır. Ülkeleri karşı karşıya da getirmektedir. İngiltere Jack Letts isimli vatandaşının geri dönme talebini reddederek, IşīD'e katıldığı ve terör faaliyetlerinde bulunduğu gerekçesiyle, halihazırda babasından dolayı Kanada vatandaşlığını alabileceğini belirterek vatandaşlıktan çıkarmıştır. Kanada ise yakın müttefiki olan İngiltere'nin böyle davranarak sorumluluktan kaçtığ 1 gerekçesiyle eleştirmiştir (The Telegraph, 2019). Unutmamak gerekir ki, vatandaşlıktan çıkarma uygulaması hukuki bir eylem olduğu için sonrasında özel hukuk problemlerinin de yaşanmasına zemin hazırlamaktadır.

Uluslararası hukuk açısından sorun yaratacak başka bir nokta ise ülkelerine alınmayan yabancı savaşçıların üçüncü ülkeler açısından yargılama ve barınma maliyetleridir. Fransa gibi kimi ülkeler yaptıkları protokollerle kendi vatandaşı olup terör örgütlerine katılan savaş̧̧ıların yargılanmasını yakalandıkları ülkeye bırakmıştır (Pugliese, 2020: 1). 27 Mayıs 2019 tarihinde 12 Fransız vatandaşı Irak mahkemeleri tarafından idama mâhkum edilmiştir. Fransız yetkililer yargılamaya taraf olmayacaklarını çünkü bunun Irak mahkemelerinin meselesi olduğunu söylemektedir (BBC, 2019). Fakat bunların tutulmas1, yargılanmas1 ve sonrasında ise serbest bırakılması üçüncü ülkeler için ciddi ekonomik ve sosyal

\footnotetext{
${ }^{6}$ Tam metinler için; https://www.unhcr.org/un-conventions-on-statelessness.html

${ }^{7}$ Benzer durum Türk vatandaşlı̆̆ını taşıyıp YPG/PKK güçlerine katılanlar içinde geçerlidir. Bu kişiler Suriye'de hem uluslararası terör faaliyetlerinde bulunmakta hem de kendi devletlerine bölgede yürütülen askeri operasyonlar kapsamında karşı çatışmaya girmekte çekinmemektedir.
} 
maliyet doğurabilir. Çünkü ülkelerin mevcut kapasiteleri üzerinde bir yük getirmekte ve aynı zamanda bu ülkeler içinde güvenlik problemleri yaratabilmektedir. Kimi durumlarda yargılama süreci sağlıklı işlemeden idam cezaları verilebilmektedir (Haider, 2014:4-8). Bu durum İnsan Hakları Evrensel Beyannamesi'nin adil yargılanma ve yaşam hakkıyla ilgili temel ilkelerine zarar vermektedir. Zaten Irak gibi ülkelerde halihazırda hukuk sistemleri sağlkklı çalışmamaktadır.

Dahası bölgenin istikrarsızlık çemberinde yer alması ve sıklıkla güç boşluklarının oluşması bu savaşçıların kimi zaman kaçmalarına veya serbest bırakılmalarına neden olmaktadır. Halihazırda Suriye'nin kuzeyinde Suriye Demokratik Güçleri (SDF) tarafindan tutulan Avrupalı yabancı terörist sayısının 2000 civarında olduğu tahmin edilmektedir (Dworkin, 2019:4). Yerel militanlarla beraber düşünüldüğünde bu sayı 12000'e kadar çıkmaktadır. Tahmin edileceği gibi bu sayı Irak ve SDF için çok büyük bir maliyet getirmektedir. Örneğin, Türkiye'nin Suriye'nin kuzeyinde gerçekleştirdiği askeri operasyonlar sırasında YPG elinde olan IŞiD tutsaklarının artık ikinci öncelikte olduğunu belirtmiş ve kamplarda güvenliği sağlayamayacaklarını ifade etmiştir (Kube ve Gains, 2019). Görüldüğü üzere geri dönemeyen, alınmayan ya da serbest bırakılan yabancı terörist savaşçılar bölgedeki güvensizlik ve istikrarsızlığın büyümesine katkıda bulunmaktadır.

\section{Sonuç}

2011'de başlayan Suriye İç Savaşı ve bölgede yaşanan gelişmeler neticesinde uluslararası ilişkilerin gündemine tekrar giren yabancı savaşçı olgusu beraberinde birçok tartışmayı da getirmiştir. Bu sorunların başında kavramsal düzeyde yürütülen tartışmalar gelmektedir. Tarihsel olarak oldukça eski dönemlere dayanmasına karşın yabancı savaş̧̧ı kavramı üzerinde uzlaşılan bir tanım mevcut değildir. Farklı kavramsallaştırma çabalarına ek olarak BMGK'nın 2178 sayılı kararıyla bu kavramsallaştırma çabası daha çetrefilli bir hale dönüşmüştür. Çünkü yabancı savaşçı olgusunu terör faaliyetleri kapsamında değerlendirilmek istenmesi yeni bir kavramın kullanılmasının önünü açtığ söylenebilir. Yukarıdaki tartışmada bahsedildiği üzere bu kavramın kullanılmaya başlanması beraberinde hangi örgütün terör örgütü olarak kabul edilip edilmediği yönünde başka bir tartışmanın yaşanmasına yol açmıştır. Devletlerin çıkarları ve güvenlik algılarına göre bu tanımlamada esnek davranıldığı gözlenmektedir. Batı ülkelerinin genel tutumunda yabancı terörist savaşçılar kavramı ile Suriye ve Irak'ta evlerinden ayrılıp IŞiD ve türevi terör örgütlerine katılan kişiler kastedilmektedir. BMGK'nın bu çabasının yabancı savaşçı olgusunu daha karmaşık hale getirdiği ve dolaylı yollardan da olsa terörün meşrulaşmasına ve propagandasına hizmet ettiği görülmektedir.

$\mathrm{Bu}$ kavramsallaştırma çabasına ek olarak Suriye iç savaşı kapsamında yabancı savaşçı ve yabancı terörist savaş̧̧ılar farklı biçimlerde oluşmaktadır. Çalışma boyunca yabancı savaşçıların ya dini motifli terör grupları şeklinde ortaya çıktığını ya da etnik-sol ideolojiye sahip gruplar şeklinde sahada 
faaliyetlerde bulunduğu ortaya konmuştur. İki grup ideolojik ve sahip oldukları motivasyonlar açısından birbirlerinin zıttı gibi görünmesine rağmen bölgedeki faaliyetleri açısından benzerlikleri oldukça fazladır. Orantısız güç kullanımı, çatışmalarda sivil halkın hedef alınması, yargısız infazlar, işkenceler, ölümcül cezalandirmalar, sivillerin kalkan olarak kullanılması, yerinden etmeler, sürgünler ve gücün kötüye kullanılması gibi faaliyetler, her iki terör grubu ve yabancı savaşçılar tarafından kullanılan ve yakın dönemde uluslararası sivil toplum kuruluşları tarafindan da yayımlanan raporlarda uluslararası insan hakları ihlalleri olarak belgelendirilmiştir. Bu faaliyetler sonuçta bölgede güvensizlik ve istikrarsızlık ortamının derinleşmesine yardımcı olmaktadır. Güvensizlik ve istikrarsızlık durumunun en belirgin sonucu ise kitlesel göçleri tetiklemesidir.

Yabancı savaşçıların da dâhil olduğu terör örgütleri ele geçirdikleri bölgelerde hakimiyetlerini pekiştirmek için yerel halka baskı yaparak yerinden etmekten çekinmemiştir. Kimi zaman kültürel yapılar kimi zaman ise yerleşim birimleri doğrudan hedef alınmış ve haritadan silinmiştir. Böylelikle bölgeden kitlesel göçlerin hızlandığı söylenebilir. Uzun vadede düşünüldüğünde Suriye'den başlayan göç dalgasının AB'nin içlerine kadar zincirleme bir şekilde ülkelerin istikrarını bozması muhtemeldir. Köylerin boşaltılması ve yerel halka yönelik etnik temizlik ve göç ettirme stratejileri uzlaşma sürecinin tamamen ortadan kalmasına neden olmaktadır. 2011'den beri devam eden iç savaş bir biçimde sona erdiğinde ve geri dönüşler konuşulmaya başlandığında ortada geriye dönülecek bir toprağın kalmadığı anlaşılacaktır. Geçen süre zarfinda sistematik biçimde köy isimlerinin değiştirilmesine paralel olarak toplumun hafızasını da yok edilmektedir.

Diğer yandan yabancı savaşçılar kapsamında ortaya çıkan başka bir sorun bu savaş̧̧ıların uyruğu olduğu ülkeler açısından gözlemlenmektedir. Ülkeler terör örgütlerine katılmış yabancı savaşçı olarak bölgede faaliyette bulunmuş olan vatandaşlarına karşı sert ve yumuşak yaklaşım olarak sınıflandırabilecek politikalar geliştirmektedir. Ceza ve rehabilitasyon mantığı doğrultusunda ortaya konulan bu politikalar yabancı terörist savaşçıların tehdit unsuru olma ihtimalini ortadan kalkmasını amaçlamaktadır. Kimi ülkeler yabancı savaşçılar için maliyet yaklaşımı geliştirmektedir. Yargılama sürecini yaptıkları protokollerle üçüncü ülkelerle devretmektedir. Bu durum daha fazla insan hakları ihlallerinin ortaya çıkmasına ve üçüncü ülkelerin ciddi maliyetlerle uğraşmasına neden olmaktadır. Birçokları tarafından eleştirilmesine rağmen İngiltere gibi bazı ülkeler ise yabancı savaşçıların ikinci bir vatandaşlık taşımaları durumunda vatandaşlığın kaybettirilmesi sürecini başlatmakta, yakın müttefikleriyle karşı karşıya gelebilmektedir. Yabancı savaşçıların silah altına alınmasının, bölgedeki faaliyetlerinin, gözetimlerinin, geri dönüşlerinin ve rehabilitasyonlarının güvenlik, istikrar ve uluslararası toplum ve hukuk açısından birçok sorun yaratığ unutulmamalidır. 
Suriye Iç Savaşında Yabancı Savaşçılar

\section{Kaynaklar}

Aboufadel, L., (19.08. 2014). Islamic State Executes Female Dentist For Treating Men. AMN - Al-Masdar News Erişim Tarihi: 11.03.2020, https://www.almasdarnews.com/article/islamic-state-executes-femaledentist-treating-men

Amnesty International, (2015, Ekim). We Had Nowhere Else To Go. Erişim Tarihi: 25.02.2020, https://www.amnesty.org/download/Documents/ MDE2425032015ENGLISH.PDF

Anadolu Ajans1, (09.01.2020). YPG/PKK releases 40 more Daesh/ISIS members. Erişim Tarihi: 1.02.2020 https://www.aa.com.tr/en/middle-east/ypg-pkkreleases-40-more-daesh-isis-members/1697604

Barnett, R. (2017). Beyond The Caliphate: Foreign Fighters and the Threat of Returnees. Erişim Tarihi: 11.03.2020, https://thesoufancenter.org/wpcontent/uploads/2017/11/Beyond-the-Caliphate-Foreign-Fighters-andthe-Threat-of-Returnees-TSC-Report-October-2017-v3.pdf

BBC News, (07.02. 2020). Shamima Begum loses appeal over citizenship. Erişim Tarihi: 11.03.2020, https://www.bbc.com/news/uk-51413040

BBC, (27.05.2019). French Islamic State members sentenced to death in Iraq. Erişim Tarihi: 05.02.2020, https://www.bbc.com/news/world-middle-east48414670 bbc 2019

Boutin, B. (2016, Aralık) Administrative Measures against Foreign Fighters: In Search of Limits and Safeguards. The International Centre for CounterTerrorism, Cilt 7(12), Erişim Tarihi: 05.02.2020, https://icct.nl/wpcontent/uploads/2016/12/ICCT-Boutin-Administrative-MeasuresDecember2016-1.pdf

Bryan, I. (2010, Kış) Sovereignty and the Foreign Fighter Problem. Orbis, Cilt 54(1), 115-129

Byman, D. \& Shapiro, J. (2014, Kasım). Be Afraid. Be a Little Afraid: The Threat of Terrorism from Western Foreign Fighters in Syria and Iraq. Foreign Policy at Brooking, 34, 1-34

Codexter, (2016). The Roles Of Women In Daesh. Erişim Tarihi: 20.02.2020, https://rm.coe.int/16806b33a7

Davis, R. (2015). Syria's Refugee Crisis, Great Decisions, 65-76.

Dearden, L. (11.02.2019). James Matthews: Former British soldier who fought against Isis attacks 'incoherent' terror charge. The Independent, Erișim Tarihi: $\quad 05.02 .2020$, https://www.independent.co.uk/news/uk/homenews/james-matthews-isis-british-soldier-terror-charge-syria-army-uka8770781.html

Defend International, (4.08.2015). UN Official Verified IS “Price List" For Enslaved Females. Erişim Tarihi: 08.02.2020, https://defendinternational.org/is-price-list-for-yazidi-and-christianfemales-verified-by-un-official/ 
Demir, H. (01.12.2019). Mezarları ve türbeleri neden yıkıyorlar?, Tepav Günlük, Erişim Tarihi: 01.03.2020, https://www.tepav.org.tr/tr/blog/s/6540/ Mezarlari+ve+turbeleri+neden+yikiyorlar_

Dworkin, A. Beyond Good And Evil: Why Europe Should Bring Iis Foreign Fighters Home. Erişim Tarihi: 20.02.2020,https://www.ecfr.eu/page//beyond_good_and_evil_why_europe_should_bring_isis_foreign_fighter s_home.pdf

Erdoğan, Ş. \& Deligöz, E. (2015, Mayıs). Irak Şam İslam Devleti (IŞiD): Gücü ve Geleceği. Savunma Bilimleri Dergisi, Cilt 14(1), 5-37

Gülşen, H. (2019, Nisan). Radikalleşme Bağlamında Yabancı Savaşçıların Evrimi. Ortadoğu Araştırmaları Merkezi, 4, 1-27

Haider, H. (12.12.2014, Formal justice in Iraq, GSDRC Helpdesk Research Report, 1175 , Erişim Tarihi: 04.03.2020,https://assets.publishing.service.gov.uk/media/57a089a6ed91 5d622c00032d/hdq1175.pdf

Hatahet, S. (2015, Şubat). Suriye'de IŞSiD. Ortadoğu Araştırmaları Merkezi, 20, $1-12$.

Hatahet, S.,Cengiz, M.E.\& Rashid, M.(2019 Nisan) Suriye'deki Ulus-Aşırı Ypg'li Savaşçılar Fenomeni. Istanbul: Al Sharq Forum

Hegghammer, T.(2013, Şubat). Should I Stay or Should I Go? Explaining Variation in Western Jihadists' Choice between Domestic and Foreign Fighting. American Political Science Review, Cilt 107(1),1-15.

Hegghammer,T. (2010, Kış) The Rise of Muslim Foreign Fighters: Islam and the Globalization of Jihad. International Security, Cilt 35(3), 53-91.

HRW, (2014). Under Kurdish Rule Abuses in PYD-run Enclaves of Syria. Erişim Tarihi: 20.02.2020, https://www.hrw.org/sites/default/files/reports/ syria0614_kurds_ForUpload.pdf

HRW, (2016). Iraq: Women Suffer Under ISIS. Erişim Tarihi: 20.02.2020, https://www.hrw.org/news/2016/04/05/iraq-women-suffer-under-isis

HRW, (2020). Iraq Events of 2019. Erişim Tarihi: 26.04.2020, https://www.hrw.org/world-report/2020/country-chapters/iraq

Karabat, A. (25.08.2015), IŞİD Devlet Olmak İstiyor. Al Jazeera, Erişim Tarihi: 05.02.2020,http://www.aljazeera.com.tr/al-jazeera-ozel/isid-devletolmak-istiyor

Kube, C. \& Mosheh, G. (08.10.2019). Top Kurdish general: Watching over ISIS prisoners now a 'second priority'. NBCNEWS. Erişim Tarihi: 26.03.2020, https://www.nbcnews.com/news/mideast/top-kurdish-general-watchingover-isis-prisoners-now-second-priority-n 1063496

Malet, D. (2013). Foreign Fighters Transnational Identity In Civil Conflicts, New York: Oxford University Press

Malet, D. (2015). Foreign Fighter Mobilization and Persistence in a Global Context. Terrorism and Political Violence, Cilt 27 (19), 454-473 
Moore, C.\& Tumelty, P. (2018) Foreign Fighters and the Case of Chechnya: A Critical Assessment. Studies in Conflict \& Terrorism, Cilt 31(5). 412-433

OHCHR, (2014, Kasım).Rule of Terror: Living under ISIS in Syria. Erişim Tarihi: 10.03.2020, https://www.refworld.org/docid/5469b2e14.html

Orton, K. (2017). The Forgotten Foreign Fighters: The PKK in Syria. The Henry Jackson Society, London, Erişim Tarihi: 05.01.2020, http://henryjacksonsociety.org/wp-content/uploads/2017/08/3053-PYDForeign-Fighter-Project-1.pdf

Pugliese, M. (09.01.2020). France and Foreign Fighters: The Controversial Outsourcing of Prosecution. Erişim Tarihi: 05.02.2020, https://www.ispionline.it/en/pubblicazione/france-and-foreign-fighterscontroversial-outsourcing-prosecution-24666

Radicalisation Awareness Network. (2017, Temmuz). Responses to returnees: Foreign terrorist fighters and their families. Erişim Tarihi: 14.02.2020, https://ec.europa.eu/home-affairs/sites/homeaffairs/files/ran_br_a4_m10 en.pdf

Raudszus, J. (09.01.2020). The Strategy of Germany for Handling Foreign Fighters Erişim Tarihi: 05.02.2020, https://www.ispionline.it/en/ pubblicazione/strategy-germany-handling-foreign-fighters-24761

Reed, A. \& Pohl, J. (2014). Ülkelerine geri dönüş yapan yabancı terör savaşçılarının artan sorunlarıyla başa çıkmak. Nato Review, Erişim Tarihi: 04.03.2020, https://www.nato.int/docu/review/tr/articles/2017/07/14/ uelkelerine-geri-doenues-yapan-yabanci-teroer-savascilarinin-artansorunlariyla-basa-cikmak/index.html

Rich, B. \& Conduit, D. (2014).The Impact of J1hadist Foreign Fighters on Indigenous Secular-Nationalist Causes: Contrasting Chechnya and Syria. Studies in Conflict \& Terrorism, Cilt 38(2), 113-131

SHRN, (2015). The Most Significant Human Rights Violations by Kurdish Democratic Union Party and the Kurdish Self-Management Forces. Erişim Tarihi: 23.02.2020,http://sn4hr.org/wp-content/pdf/english/Violations_ by_the_Kurdish_Self_Management_Forces_en.pdf

SHRN, (2016). The Yearly Report for 2016. Erişim Tarihi: 23.02.2020, http://sn4hr.org/wp-content/pdf/english/The_Yearly_Report_for_2016 en.pdf

State, (2016). Trafficking in Persons Report. Erişim Tarihi: 14.02.2020, https://2009-2017.state.gov/documents/organization/258876.pdf

The Telegraph, (19.08.2019). Jihadi Jack: Canada accuses UK of 'off-loading its responsibilities' by stripping Isil fighter of citizenship. The Telegraph Erişim Tarihi: 26.03.2020, https://www.telegraph.co.uk/news/2019/08/19/ jihadi-jack-canada-disappointed-uk-has-off-loadedresponsibilities/

UNHRC, (2014). Global Trends Forced Displacement in 2014. Erişim Tarihi: 26.04.2020,https://www.unhcr.org/556725e69.html\#_ga=1.237703683.28 1529137.1434611844 
UNOCT, (2017). Enhancing the Understanding of the Foreign Terrorist Fighters Phenomenon in Syria. Erişim Tarihi: 14.02.2020, http://www.un.org/en/counterterrorism/assets/img/Report_Final_2017072 7

UNSC, (2019, Temmuz). Report of the Secretary-General on Children and armed conflict. S/2019/509, Erişim Tarihi: 25.02.2020, https://www.un.org/sg/ sites/www.un.org.sg/files/atoms/files/26-07-2019_SG_CAAC_report advance copy 0 .pdf

UNSC, 24.09.2014, Resolution 2178. Erişim Tarihi: 14.02.2020, https://www.undocs.org/S/RES/2178\%20(2014)

Ünver, H., (2018). Contested Geographies: How ISIS and YPG Rule "No-Go" Areas in Northern Syria. In: Ö. Oktav, E. Dal and A. Kurşun, ed., Violent Non-state Actors and the Syrian Civil War. Springer, pp.35-51.

Yalçınkaya, H. (2017). IŞiD'in Yabancı Savaşçıları ve Yarattığı Tehdit: Türkiye'nin Tecrübesi (2014- 2016). Uluslararası İlişkiler, Cilt 14 (53), 23 43

Zuijdewijn, J.R. \&Bakker, E. (2014, Haziran) Returning Western Foreign Fighters: The Case of Afghanistan, Bosnia and Somalia, International Centre for Counter-Terrorism Background Note, Erişim Tarihi: 11.03.2020, https://www.icct.nl/download/file/ICCT-De-Roy-vanZuijdewijn-Bakker-Returning-Western-Foreign-Fighters-June-2014.pdf 